\title{
Relationship Between Adherences of Antiretroviral (ARV) Consumption with Viral Load in HIV/AIDS
}

\author{
Indah Jayani $^{1}$, Susmiati ${ }^{2}$, \\ Yudied Agung Mirasa ${ }^{3}$, \\ Khusnul Khotimah ${ }^{4}$ \\ ${ }^{1,2,3,4}$ Nursing Program, Faculty of \\ Health Sciences, Kadiri University \\ Email: \\ indah.jayani@unik-kediri.ac.id
}

Received : October $4^{\text {nd }} 2021$

Accepted : October 15 2021

Published : November $27^{\text {th }} 2021$

\begin{abstract}
Viral load testing is an informative and sensitive method for successful HIV / AIDS therapy. This study aims to determine the relationship between adherence to viral antiretroviral consumption and viral load in people with HIV/AIDS. This research is a correlational analytic study using a cross-sectional approach. The population in this study was 34 people and, the number of samples was 32 using the purposive sampling technique. The research sample in this study was 32 respondents. The test results using the Spearman Rank obtained p-value 0,00 $>0,05$. It was concluded that there was a relationship between adherence to antiretroviral drugs and viral load. Advice for people with HIV / AIDS is expected to increase adherence to ARV consumption so that viral load is low and undetectable so that CD4 cell count increases and disease prognosis improves.
\end{abstract}

Keywords: Adherence, consumption of ARV, viral load, HIV/AIDS

Copyright $@ 2021$ IIK STRADA Indonesia All right reserved.

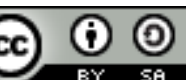

This is an open-acces article distributed under the terms of the Creative Commons Attribution-ShareAlike 4.0 International License.

\section{INTRODUCTION}

Acquired Immune Deficiency Syndrome (AIDS) is a collection of signs and symptoms of disease due to loss or decline in a persons immune system due to the Human Immunodeficiency Virus (HIV). This virus infects cells of the immune system, destroying it and even destroying its function. HIV infection causes progressive damage to the immune system, resulting in AIDS (WHO, 2014). WHO announced that 36,9 million people in the world have the HIV virus with the highest prevalence in Africa. Asia ranks third with a prevalence of 3,5 million people after America (Khairunisa, Saraswati, Lintang Dian Adi, Mateus Sakundarno, 2017). The number of deaths due to HIV / AIDS in the world in 2008 was around 2,6 million people. Meanwhile, the mortality rate for people with AIDS in Indonesia is 7,293 until September 2013 (Ditjen PP \& PL Kementerian Kesehatan RI, 2016). Based on the Ministry of Health Disease Control and Prevention (P2P) data, until March the number of HIV sufferers had reached 242,699 and, AIDS sufferers had reached 87,453 people. According to the Indonesian Ministry of Health, the number of reported incidents of HIV infection in East Java as of March 2017 was 33,043. Based on a report from the Kediri District Health the number of HIV / AIDS sufferers in 2017 reached 1200 people data on HIV sufferers revealed that up to September 2017, the number of HIV / AIDS sufferers was 207 people. Data with HIV / AIDS known in KPAD in 2017 as many as 739 people, 544 of whom had met the requirements for ARV, 505 people had ARV and, 304 people were still on ARV. 
Meanwhile, 109 and 44 people died and passed the follow-up respectively, (Dinas Kesehatan Kabupaten Kediri, 2017). Meanwhile, data obtained from the Kediri District Health Office in 2019 stated that 55 people with HIV / AIDS died each and passed 97 follow up in 2019 (Dinas Kesehatan Kabupaten Kediri., 2019).

Based on a preliminary survey in the Kediri area on December 8, 2019, data on HIV / AIDS sufferers were obtained that there were 885 people living with HIV / AIDS (PLWHA). The results of a preliminary study conducted on $10 \mathrm{HIV} /$ AIDS patients where $80 \%$ had moderate adherence and $20 \%$ had low adherence. Non-compliance with ARV consumption is caused by new PLHIV or people who have recently been diagnosed with HIV and are still hiding their HIV / AIDS status. In addition, it is not customary to take medicine every day and on time.

The prognosis of infection with this disease can be seen in addition to the CD4 cell count and viral load, so the results of these two tests can be used as predictors of HIV complications. Viral load testing is an informative and sensitive method for therapeutic efficacy. Treatment was said to be virologically successful if the HIV-1 plasma RNA level was below 400 copies/ml or 50 copies $/ \mathrm{ml}$ after 6 months of therapy. The success of therapy can be seen from the clinical signs of patients who improve after therapy, one of which is that opportunistic infections do not occur. The viral load and the treatment carried out are antiretroviral therapy, this treatment requires adherence to PLWHA so that resistance does not occur, and can reduce the number of viruses in CD4 cells. This study aims to determine the relationship between adherence to viral antiretroviral consumption and viral load in HIV/AIDS patients

\section{MATERIALS AND METHODS}

This research design uses correlational analytic with a cross-sectional approach. The data used in this study are secondary data to see the viral load variable and primary data to measure the variable compliance with ARV consumption. The population in this study are 35 people with HIV / AIDS in the Kediri area and, with a purposive sampling technique, a sample of 32 people was obtained. The instrument used to measure adherence to ARV consumption variables was the MMAS questionnaire (adherence to taking medication according to (Morisky D.E.Ang, A.Krousel-Wood, M.A.Ward, n.d.) and to see the viral load value with a data collection sheet. Data analysis to determine the relationship between compliance with ARV consumption and viral load using the Spearman rank correlation test with a significance of $\alpha=0,005$.

\section{RESULTS}

Demographic data on respondent characteristics included gender, age, education, occupation and, marital status, are presented in the table below.

Table 1. Characteristics of respondents

\begin{tabular}{llcc}
\hline \multicolumn{1}{c}{ Variable } & & Amo & \% \\
& & unt & \\
\hline Gender & Male & 19 & 40.6 \\
& Female & 28 & 59.4 \\
& Early teens (16-20 years) & 0 & 0 \\
& Late teens (21-25 years) & 1 & 3.1 \\
& Early adulthood (25-35 years) & 7 & 21.9 \\
& Late adulthood (36-45 years) & 15 & 46.9 \\
& Early elderly (>45-50 years) & 9 & 28.1
\end{tabular}


Late elderly ( $>50$ years)

$\begin{array}{ll}\text { Education } & \text { No school } \\ & \text { Primary school } \\ & \text { Secundary school } \\ & \text { High school } \\ \text { Occupations } & \text { No work } \\ & \text { Private } \\ & \text { Civils } \\ \text { Marital } & \text { Single } \\ \text { Status } & \end{array}$

Married
28.1

6.3

71.9

21.9

0

21.9

75.0

3.1

6.3

93.8

Source : Research data, 2020.

Based on table 1, it shows that the characteristics of the respondents are mostly (59.4) female, and most $(68.75 \%)$ are in the adult age range (25-45 years). The results of this study are consistent with previous studies showing that the number of HIV / AIDS sufferers was mostly women because most of the respondents had a background as ex-FSW most of them were of productive age. Where the productive age is vulnerable to HIV / AIDS transmission (Jayani \& Ruffaida, 2019). Most of the 23 respondents (71.9\%) have primary school education (SD, SMP). It was stated that PLWHA with higher education had a 4.55 times greater chance of having a good quality of life than PLWHA with low education (Handayani \& Dewi, 2017). Almost all 24 respondents (75\%) work privately. Most of the respondents in this study were ex-FSW, so they are included in the vulnerable group of HIV transmission. Almost all respondents $(93.8 \%)$ are married. According to research conducted by (S et al., 2014) that someone who has a partner has a place to share, expresses feelings for each other so that someone who is married has better support

Table 2. Relationship between adherence to ARV consumption and viral load

\begin{tabular}{lccc}
\hline \multicolumn{1}{c}{ Aherence } & \multicolumn{2}{c}{ Viral Load } & Total \\
\hline Low & Detected & $\begin{array}{c}\text { Not } \\
\text { Detected }\end{array}$ & \\
Moderate & 9 & 0 & 9 \\
High & 4 & 13 & 17 \\
Correlation Coefficient $=\mathbf{0 . 7 4 1}$ & 0 & 6 & 6 \\
P value $=\mathbf{0 . 0 0 0} \boldsymbol{\alpha}: \mathbf{0 . 0 0 5}$ & & \\
\hline
\end{tabular}

Source : Research data, 2020.

Based on table 2. shows the results of the correlation test using the Spearman Rank alpha 0.05 , the $\mathrm{p}$-value is 0,00 so that $<\alpha=0,005$. It was concluded that the hypothesis $\mathrm{H} 0$ was rejected and, $\mathrm{H} 1$ was accepted so that it was interpreted that there was a relationship between ARV consumption adherence and the viral load of HIV patients in the Kediri area. Patient adherence affects the success of treatment. The results of therapy will not reach the optimal level without the awareness of the patient it can even lead to failure of therapy and can also cause complications that are very detrimental (Hussar, 1995).

\section{DISCUSSION}

Based on the results of the research that has been done, it can be seen that most of the respondents $(53.1 \%)$ have moderate compliance. This was confirmed by previous researchers (Denia Pratiwi, 2011), that patient adherence affects the success of a treatment. This result is contrary to the results of a study conducted by Elizabet from Diponegoro University Semarang (2010) which states that there is no significant relationship between viral load and 
CD4 count in HIV / AIDS sufferers. Patients with HIV / AIDS must achieve adherence to ARV treatment (antiretroviral) 90\% - 95\%, which means $90 \%-95 \%$ of all doses must be taken on time ((Latif, Fachri, Ida Leida Maria, 2014)Based on previous research (Astari, Safitri, and P 2007) there is a significant relationship between the level of adherence to ARV treatment and CD4 viral load (Danik Astuti, 2016).

Research results at RSUP. Dr. Kariadi Semarang (Herlambang Sasmita Aji, 2010) shows that out of 70 HIV-AIDS sufferers, more than half of HIV-AIDS sufferers $(71.4 \%)$ have a high level of adherence in taking ARVs given in the last month and the rest $(28.6 \%)$ have low adherence. According to Hussar (1995) quoted from (Denia Pratiwi, 2011), patient adherence affects the success of the treatment. The results of therapy will not reach the optimal level without the awareness of the patient, it can even lead to failure of therapies, and can also cause very detrimental complications. Adherence is the level of a person in carrying out a rule and behavior recommended by health workers in achieving virological success of antiretroviral therapy in order to be able to suppress viral replication maximally. Patients with HIV / AIDS must achieve adherence to ARV treatment (antiretroviral) 90\% - 95\%, which means $90 \%$ - 95\% of all doses must be taken on time (Latif, Fachri, Ida Leida Maria, 2014). Based on research in 2004, in the United States and Europe, 10\% of new HIV / AIDS infections showed resistance to ARVs (Khairunisa, Saraswati, Lintang Dian Adi, Mateus Sakundarno, 2017).

The HIV virus cannot be eliminated from the body of an infected person, but the numbers can be suppressed with ARV therapy. This virus always replicates itself all the time, so it takes a very high adherence to taking ARV drugs so that drug levels in the blood can always be maintained at a therapeutic concentration for optimal strength and drug action. Thus the HIV virus does not have the opportunity to replicate itself. Adherence to the use of ARV drugs is critical to obtaining the full benefits of ARV therapy included maximizing long-term suppression of viral replication, reducing damage to CD4 cells, preventing viral resistance, boosting immunity, and slowing disease progression (Permatasari, J., 1, Almasdy, D., 2, 2017).

The results of previous studies showed a significant relationship between the level of adherence to ARV treatment and CD4 viral load. Based on research conducted by (Homayoon et al., 2013) it was found that the viral load was lower in women than men even with the same CD4 cell count. The HIV viral load test is a test used to measure the amount of HIV virus in the blood, while the amount of HIV virus in the blood is called viral load, which is expressed in units of copies per milliliter (mL) of blood. By measuring HIV RNA in the blood, it can directly measure the amount of viral replication. This virus needs RNA to print or ablue print in order to produce a new virus. Each HIV virus carries two copies of the RNA. This means that if the test results show the amount of HIV RNA of 20,000 copies per mL, which means that in every milliliter of blood, there are 10,000 virus particles. Plasma viral load was the best single predictor in determining the clinical outcome of HIV infection, followed by second (based on predictive value) CD4 T-lymphocyte count, then neopterin level, B2-microglobulin level, and thrush or fever (Miners et al., 2014).

Treatment or antiretroviral therapy (ARV) has the goal of suppressing the maximum HIV replication. So that it can increase the chances of survival, however, if you do not adhere to drug use properly, the disease can persist and, treatment can fail. Patients must understand that the rules for medication must be obeyed carefully and can be needed for several years or for a lifetime (Y Indria. K Teguh. U Anna. S Koesnoe, 2015b). Apart from these goals, there are still several goals that are expected to be achieved from ARV treatment or therapy, such as; reduce the rate of HIV transmission to the community, restore or maintain immunological function (stabilization or increase in CD4 cells), reduce complications due to HIV, suppress the maximum and continuous viral replication and reduce the morbidity and mortality rates associated with HIV (Muchlis A.U Sofro, 2013). 
According to research (Y Indria. K Teguh. U Anna. S Koesnoe, 2015a). the life expectancy of people with HIV at age 20 who was diagnosed late or delayed treatment until a CD4 count $<200$ cells $/ \mathrm{mm}^{3}$ had a life expectancy of 10 years shorter than patients who followed treatment instructions, which recommended that patients start treatment. ARVs when the CD4 count goes up. Based on the above phenomena, the researchers conducted a study related to the correlation between ARV consumption adherence and viral load examinationAdherence really determines how successful antiretroviral treatment is in increasing CD4 cells because if someone forgets to take one dose or once, the virus will multiply (Dhika Ayu Kurnia, 2018). Adherence to the consumption of ARV drugs that can suppress or inhibit the increase in viral load levels in the body of people with HIV / AIDS, although it cannot be used as an indicator of recovery. High drug consumption will increase immunity or immunity in the body, whereas if immunity increases, viral load levels will be low or undetectable.

\section{CONCLUSION}

1. Adherences with ARV consumption among HIV / AIDS sufferers in the Kediri area was mostly moderate.

2. Viral load in HIV / AIDS sufferers in Kediri area were mostly detected.

3. There is a relationship between compliance with ARV consumption and viral load among HIV / AIDS sufferers in the Kediri area.

Advice for people with HIV / AIDS is expected to increase adherence to ARV consumption so that viral load is low and undetectable and CD4 count increases so that the disease prognosis improves.

\section{REFERENCES}

Danik Astuti. (2016). Nurse Role As Educator Affected the Adherence of Antiretroviral ( ARV ) Consumption For Patients with HIV / AIDS in the VCT Clinic of Dr. Moewardi Hospital ). 183-88.

Denia Pratiwi. (2011). Effect of drug counseling on adherence of hypertensive patients in special polyclinic RSUP DR.M.Djamil Padangg. https://www.onesearch.id/Record/IOS2779.slims-61941

Dhika Ayu Kurnia, U. S. (2018). The Relationship between Knowledge of HIV / AIDs, Antiretroviral Therapy, and Opportunistic Infections to the Compliance of PLWHA in Undergoing Antiretroviral Therapy. Faletehan Health Journal, 5(2), 84-89.

Kediri District Health Office. (2019). Kediri District Health Profile. www.dinkes.kedirikab.go.id

Kediri District Health Office. (2017). Kediri District Health Profile 2017.

Ditjen PP \& PL Kementerian Kesehatan RI. (2016). Laporan perkembangan situasi HIV \& AIDS Di Indonesia Triwulan 2 Tahun 2016. Dinkes Jawa Timur.

Handayani, F., \& Dewi, F. S. T. (2017). Faktor yang memengaruhi kualitas hidup orang dengan HIV / AIDS di Kota Kupang Factors affecting quality of life of people living with HIV / AIDS in Kupang.

Herlambang Sasmita Aji. (2010). Adherence of HIV and AIDS Patients to Antiretroviral Therapy in Semarang, Kariadi Hospital.

Jayani, I., \& Ruffaida, F. S. (2019). Predisposing Factors Knowledge, Attitudes, Values and Culture of Ex-Sexual Working Women with HIV/AIDS Incidence in Education Areas. 7(1), 53-63. 
Khairunisa, Saraswati, Lintang Dian Adi, Mateus Sakundarno, A. (2017). Overview of Adherence to Arv (Antiretroviral) Medication (Study of HIV / Aids Positive Female Sex Workers in Batang District). Jurnal Kesehatan Masyarakat, 5(4). http://garuda.ristekbrin.go.id/documents/detail/1424364

Latif, Fachri, Ida Leida Maria, and M. S. (2014). Side Effects on Adherence to Antiretroviral Treatment among People Living with HIV / AIDS ((90245): 1).

Miners, A., Phillips, A., Kreif, N., Rodger, A., Speakman, A., Fisher, M., Anderson, J., Collins, S., Hart, G., Sherr, L., Lampe, F. C., Johnson, M., McDonnell, J., Aderonke, A., Gilson, R., Edwards, S., Haddow, L., Gilson, S., Broussard, C., ... Burman, B. (2014). Health-related quality-of-life of people with HIV in the era of combination antiretroviral treatment: A cross-sectional comparison with the general population. The Lancet HIV, 1(1), e32-e40. https://doi.org/10.1016/S2352-3018(14)70018-9

Morisky D.E.Ang, A.Krousel-Wood, M.A.Ward, H. (n.d.). Predictive Validity of A Medication Adherence Measure in an Outpatient Setting. J. Health-Syst. Pharm, 10: 348-54.

Muchlis A.U Sofro, E. F. P. (2013). Relationship Between Clinical Stage, Viral Load and CD4 Count in Patients with Human Immunodeficiency Virus (Hiv) / Acquired Immuno Deficiency Syndrome (Aids) Stadium Klinis, Viral Load, Jumlah CD4, HIV/AIDS. 1 (12).

Permatasari, J., 1, Almasdy, D., 2, \& R. 3. (2017). The Effect of Pharmacist Counseling on Knowledge and Compliance of HIV/AIDS Patients in the VCT Polyclinic Dr. M. Djamil Padang. 3 (May), 1.

S, D. N., Parjo, \& Dewi, A. P. (2014). Factors Affecting Quality of Life of HIV Patients Undergoing Outpatient Care at the Care Support and Treatment (CST) Mental Hospital Bangkong River Region, Pontianak City. 48, 1-14.

WHO. (2014). Human Immunodeficiency Virus HIV/AIDS. http://www.who.int/features/qa/71/en/.

Y Indria. K Teguh. U Anna. S Koesnoe. (2015a). Factors Associated with CD4 Rise in HIV Patients Receiving 21 Highly Active Antiretroviral Therapy in the First 6 Months. J. Penyakit Dalam Indonesia, 2(4), 217-222.

Y Indria. K Teguh. U Anna. S Koesnoe. (2015b). Factors Associated with CD4 Increase in HIV Patients Receiving 21 Highly Active Antiretroviral Therapy in the First 6 Months. Jurnal Penyakit Dalam Indonesia, 2(4), 217-222. 